УДК 373.3.018.1:37(477.83)(092)

DOI:

Любов Скалич, кандидат психологічних наук, доцент кафедри педагогіки та методики початкової освіти Дрогобииького державного педагогічного університету імені Івана Франка

\title{
РОДИННЕ ВИХОВАННЯ УЧНІВ ПОЧАТКОВОЇ ШКОЛИ ЗА ТВОРАМИ МИРОСЛАВА СТЕЛЬМАХОВИЧА
}

У статті розглянуто позицію Мирослава Стельмаховича щуодо родинного виховання учнів початкової школи. Зроблено аналіз положень з його праць, які можуть бути покладені в основу концепції сімейного виховання, створеної педагогом, та використовуватись у сучасній практиці початкової освіти.

Акцентовано увагу на тому, щуо сам спосіб життя сім'ї, взаємини між ї̈ членами впливають на підготовку дітей у майбутньому до створення ӥх сім'

Ключові слова: виховання; родинне виховання; украӥнська сім'я; народна педагогіка; образ матері; образ батька.

תim. 7.

Lyubov Skalych, Ph.D.(Psychology), Associate Professor of the Pedagogy and Methodology of Primary Education Department Drohobych Ivan Franko State Pedagogical University

\section{FAMILY EDUCATION OF THE PRIMARY SCHOOLCHILDREN BASED ON THE WORKS OF MYROSLAV STELMAKHOVYCH}

The article examines the position of Myroslav Stelmakhovych concerning family education of the primary schoolchildren. It analyzes the basic principles of his works, they can be the basis of the concept of family education, created by pedagogue; and they can be used in the modern practice of primary education. They are devoted to the principles of national education, the education of Ukrainian character. The article analyzes national approaches to the educational process. The necessity of mastering spiritual treasures of the Ukrainian people by each personality is substantiated; the horizons of religious education are expanded.

The importance of the national idea in the family education of primary schoolchildren is revealed; the basic directions of pedagogical science are determined, in which the development of folk pedagogy takes the main place. It is noted that the mastering folk traditions by children and youth prevents spirituality, promotes moral enrichment.

The attention is paid to the fact that the lifestyle of the family itself, the relationship between its members affects the preparation of children to the creation of their family in the future. The problems of upbringing in the Ukrainian family from ancient times to the present are investigated.

The role of father and mother in the upbringing of children is shown; it is analyzed the enormous educational effect of grandparents on their grandchildren.

The article reveals the importance of the native language as a powerful means of the upbringing of children in the family. The role of lullabies, fairy tales, fun stories and tongue twisters in the family education of primary schoolchildren is proven.

Attention is paid to the need to use the content of school education, extracurricular work, and the activities of public organizations to prepare boys and girls for the creation of a family in the future.

Keywords: an education; family education; Ukrainian family; folk pedagogy; the image of mother; the image of father.

П остановка проблеми. Українську педагогіку сьогодні неможливо уявити без імені Мирослава Стельмаховича. Педагогічна практика сільського вчителя і педагогічна теорія науковця відомі далеко за межами України. Праці педагога, його ідеї і сьогодні допомагають у професійній діяльності педагогам, а також усім, хто не байдужий до проблем родинного виховання.

Образ батька і матері глибоко хвилював педагога, він вважав, що все починається з сім’ї. Сім'я, на його думку, - це життєдайний осередок, що приводить на світ божий, плекає найвищу цінність людства - дітей, цвіт нації, майбутне народу, завдяки яким кожний батько і мати мають реальну можливість продовжувати себе в своїх потомках.

Аналіз останніх досліджень і публікацій. Аналізупедагогічної діяльності М.Г. Стельмаховича присвячені праці О. Вишневського, Д. Луцика, В. Ортинського та інших. Проблема, порушена в назві статті, є багатогранною, iї окремі аспекти досліджують українські та зарубіжні вчені.

Мета статті полягає в аналізі творів 


\section{РОДИННЕ ВИХОВАННЯ УЧНІВ ПОЧАТКОВОЇ ШКОЛИ ЗА ТВОРАМИ МИРОСЛАВАСТЕЛЬМАХОВИЧА}

Мирослава Стельмаховича з проблем родинного виховання учнів початкової школи.

Виклад основного матеріалу. Школа і сім'я мають значний потенціал у вихованні дітей у дусі толерантності як незамінної основної цінності їх розвитку і соціалізації [1, 15]. Мирослав Стельмахович належав до цієї когорти видатних учених, які 3 перших днів проголошення незалежності України утверджували чіткі орієнтири відродження і розвитку національної системи освіти і виховання, наукової і народної педагогіки.

Українська національна ідея надихала великого сподвижника в царині педагогічної науки на значущі наукові звершення. Він створив потужну науково-педагогічну школу, визначав основні напрямки розвитку педагогічної науки, в яких чільне місце займає розвиток народної педагогіки. Він жив за законами Краси і Добра, Правди, Гідності і Справедливості.

Перу видатного вченого належить більше 300 праць. Всі вони глибоко наукові, аналітичні, тісно пов'язані з практикою національного виховання дітей і дорослого населення. Його наукові запити досить широкі. Одноосібно і у співавторстві видав багато монографій, підручників, посібників, програм і концепцій національного виховання, 3 історії педагогіки, українознавства, відродження українського шкільництва.

У своїх працях “Мудрість народної педагогіки”, “Педагогіка життя", "Народна дидактика”, “Традиції української народної педагогіки” та інших М. Стельмахович виявив свою непохитну національну свідомість і громадянську мужність та патріотизм. У названих працях, як у фокусі, злилися духовні сили українського народу на рівні етнопедагогіки.

Незважаючи на спротив ділків від педагогіки і ненависників всього українського, академік М. Стельмахович довів животворчу силу народної педагогіки, джерела якої сягають в глибину століть і $є$ духовним багатством нашого народу. Так, Мирослав Стельмахович зазначав: “Засвоєння дітьми й молоддю народних національних традицій, фундаментальних знань з рідної мови, фольклору, етнографії запобігає історичному безпам'ятству, бездуховності, сприяє моральному збагаченню, прилученню до світської загальнолюдської культури через рідну культуру” $[4,140]$.

Фундаментальні монографії "Українська родинна педагогіка", “Українське родинознавство”, "Українське дитинознавство” та інші відзначаються глибиною проблеми родинного виховання, адже традиційна українська родина - перша школа любомудрості, національного виховання, світлиця моральних і благородних вчинків, плекальниця пошанівку рідної мови, народних традицій, звичаїв, обрядів, символів побутової і громадської культури.

Надзвичайно злободенні думки вченого про те, що від стану сім'ї, охорони домашнього вогнища, батьківства, дитинства й материнства у вирішальній мірі залежить не тільки особисте благополуччя кожної людини, але й життєва міць народу, української держави.

У працях, присвячених принципам національного виховання, українського характеру, учений розкривав національні підходи освітнього процесу, обгрунтовував необхідність оволодіння кожною особистістю духовними скарбами українського народу, розширював обрії релігійного виховання, будив і плекав у серцях і душах батьків педагогічну національну гідність, свідомість самосвідомість. 3 болем у серці переживав Михайло Стельмахович про долю української сім'ї. “Зневірена, зневажена сім'я, - писав він, загублене покоління, втрачене майбутнє” $[5,8]$.

Крізь призму мінливого сучасного він вдумується в минуле, досліджує проблеми виховання в українській сім'ї з найдавніших часів і до сьогодення. В умовах української незалежної держави “настав той вирішальний час, коли потрібно якнайрішучіше повернутися до українського народного родинознавства на Україні, до відродження традиційного статусу української родини з її непорушним авторитетом, подружньою вірністю, любов'ю до дітей і відданістю святому обов'язку їх виховання, повагою до батьків, материнським покликанням жінки, підняти роль чоловіка - дружини, батька матері..." [6, 5].

Учений турбувався про те, щоб українська сім'я була міцною, щоб менше було розлучень, дитячих трагедій. На його думку, слід пропагувати народні погляди на сім'ю, на кохання. Це насамперед стосується поглядів на кохання. Ось що говорив народ про це почуття: “Любов, як перстень, не має кінця”, “Сухар з водою, аби серце з тобою”, “Як гляне - серце в’яне”, “Душа душу чує в серце серцю вість дає”, “Закохався як чорт в суху вербу”, “Хоч нема що їсти, аби було $з$ ким сісти".

Мирослав Стельмахович наголошував, що народ високо цінив вірність і рівноправність у сімейному житті: "Нема кращого друга, як вірна супруга”, “Жінка чоловікові подруга, а не прислуга”, “Куди голка, туди й нитка, куди чоловік - туди й жінка", “Як чоловік жінку любить, то й лиха жінка доброю буде”, “Живуть між собою, як голубів пари”. 


\section{РОДИННЕ ВИХОВАННЯ УЧНІВ ПОЧАТКОВОЇ ШКОЛИ}

ЗА ТВОРАМИ МИРОСЛАВАСТЕЛЬМАХОВИЧА

Сімейна народна педагогіка, на думку педагога, багата прикладами виховання в дітей почуття поваги і шани до своїх батьків, і в першу чергу до мами. Адже мати дає життя, вона не тільки ростить дитину, вона є першим ï вихователем. Мати в Україні була завжди носієм доброти, ласки, справедливості, ніжності і добра. “Для кожної дитини її мама серед усіх людей найкраща, найдорожча, найближча", - зазначав Мирослав Стельмахович. I далі на підтвердження цього положення він наводить такі афоризми: "Нема цвіту кращого від маківочки, нема роду милішого від матіночки”, “Найдорожча пісня, 3 якою мати колисала”, "Рідної матері слівце - як літне сонце”, “Тільки в світі правди, що рідная мати”, “Одна мати - вірна порада”, “Материнська молитва і з дна моря підійме”, “Так гарно як у мами" $[5,103]$.

Учений наголошує і на тому, що “кожний порядний батько хоче мати добрих спадкоємців” (“добрий батько не хоче мати лихого сина”). В свою чергу, кожна дитина хоче мати тата, бо “добре тому, хто має батька, бо в батька найтепліша хатка”, “своя хата - своя стріха, свій батько - своя втіха", “таткова хата усім багата" $[5,113]$.

Мирослав Стельмахович звертав увагу на те, щоб не забувати дідусів і бабусь, бо вони самовіддано люблять онуків, їх виховний вплив незамінний. "Саме дідусь і бабуся, - писав він, як старші люди в сім’ї та громаді, наділені природним розумом, добротою, людяністю, чесністю, працьовитістю, життєвим досвідом, $є$ найпершими й найактивнішими носіями родинної педагогіки, народної виховної мудрості. Тому й вплив на онуків надзвичайно сильний, а виховна роль - величезна" $[5,119]$.

Академік Стельмахович вважав, що могутнім засобом виховання дітей у сім'ї є рідна мова. Зокрема він писав: "Батькам треба знати та й дітям своїм розказати, що українська мова $\epsilon$ національною мовою великого європейського народу i виступає як одна 3 давніх, високорозвинених мов світу, якою повинен пишатися й залюбки користуватися кожен українець" [5, 119], адже мова - одна із ознак нації. Відмирає мова - вмирає нація. Боротьба за чистоту мови для українців набуває особливого значення в умовах, коли вона стає державною.

Материнська українська мова, як стала державною, передана дитині з маминим молоком, повинна проникнути у всі пори дитини, повинна бути сприйнята розумом і серцем та пронесена через все життя. Мирослав Стельмахович вважає, що в родинному вихованні велике значення мають “колискові пісні, пестушки, потішки, забавлянки, небилиці, казки про тварин, чарівні казки, бувальщина..., заклички, примовки, прислівки, ігрові пісні..., скоромовки, дражнили, прозивалки" [2, 22].

Мирослав Стельмахович правильно відзначив, що в сімейному вихованні велику роль відіграють традиційні родинні звичаї та обряди українців. “Цілком доречним буде наголосити, що протягом багатовікової історії український народ створив, примножив і зберіг у своїй памяті та передав для використання нащадкам багату за змістом, духовним та емоційним вираженням сімейну обрядовість, пов'язану з народженням дитини, вибором кумів, імені, хрещенням, проведення обіду на честь новонародженого, першим купанням та інше" $[3,13]$.

Водночас він привертав увагу на необхідності використання в родинному вихованні національних звичаїв і релігійних традицій українського народу.

3 цього приводу Мирослав Стельмахович писав: “Вироблені і унаслідовані народом протягом віків національні звичаї мають вельми велике значення. Без опори на українські народні звичаї виховати справжнього українця неможливо. Тому їх збереження й збагачення та неухильне дотримання має доленосне значення як для нації в цілому, так і для кожного українця зокрема" [5, $35-36]$.

Мається на увазі народно-перекладні звичаї, що зв'язані з відзначенням свят у різні пори року та відзначення свят історичної ваги. Дотримання національних і релігійних традицій у родинному вихованні виховує в дітей глибокі національні почуття, патріотизм, духовність, моральність. "В усіх народів світу існує повір'я, - відзначав Олекса Воропай, - що той, хто забув звичаї своїх батьків, карається людьми і Богом. Він блукає по світі, як блудний син, і ніде не може знайти собі притулку та пристановища, бо він загублений для свого народу”.

Мирослав Стельмахович глибоко усвідомлював, що високий рівень розлучень, недоліки в сімейному вихованні дітей виникають тому, що молоде покоління не підготовлене до створення сім’ї. А морально не підготовлені до народження і виховання дітей батьки є великим нещастям для суспільства, для майбутньої долі дітей.

Мирослав Стельмахович акцентує увагу на

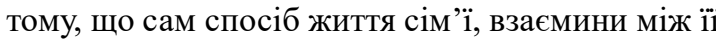
членами впливають на підготовку дітей до майбутньої ролі батька і матері. "Глибокі враження, одержані в сім’їу дитячому віці, - зазначає він, - здебільшого визначають сімейну позицію ії виховання тоді, коли стає дорослим” [5, 212]. 
М.Г. Стельмахович вважає, що в підготовці молоді до сімейного життя велику роль відіграє етнопедагогіка. Тому дуже важливо, щоб батьки використовували набутки етнопедагогіки, які стосуються функціонування сім' $\epsilon$, iї виховних функцій. “Дошлюбна підготовка в українському родинознавстві зводиться до створення міцної, здорової, щасливої сім’'і, що не знає чвар і розбрату, а тим більше розлучень" $[5,215]$.

Разом 3 тим Мирослав Стельмахович звертав увагу на необхідність використання змісту шкільної освіти, позакласної і позашкільної роботи, діяльності громадських організацій для підготовки юнаків і дівчат до виконання місії батька і матері, чоловіка і дружини.

Підготовка юнаків і дівчат до сімейного життя повинна проводитись школою, сім'єю та громадськістю. “Така єдність, - як зазначає М. Фіцула, - $є$ однією з умов оптимізації виховного процесу” [7, 245]. “Таким чином, - писав Мирослав Стельмахович, - підготовка молоді до шлюбного життя виступає, $з$ одного боку, як частина загального формування особистості, а 3 другого - включає також спеціальні виховні дії щодо озброєння підростаючих поколінь знаннями й уміннями 3 народної педагогіки. Від цього у великій мірі залежить, на яку дорогу виведе людину стежина з рідної домівки" $[6,50]$.

Висновки. Отже, багата науково-педагогічна спадщина видатного педагога - це результат його плідної роботи і невтомного дослідництва, що випливало з самого життя і не було надуманим. Вона - неоціненне джерело для успішної професійної діяльності кожного вчителя. Його праці слугуватимуть усім, кому не байдужі проблеми родинного виховання. Видатний учений увійшов в історію педагогічної думки як патріот України, добротворець і великий гуманіст. Його праці з проблем підготовки молоді до сімейного життя мають не тільки теоретичне, але й практичне значення. Ці праці використовують в українських родинах, у школах і вузах, готуючи молодь до створення сім'ї.

Перспективи подальших досліджень вбачаємо у вивченні творів М.Г. Стельмаховича у практиці сучасної підготовки майбутніх учителів.

\section{ЛІТЕРАТУРА}

1. Савченко О.Я. Виховний потенціал початкової школи. Київ, 2009. 225 с.

2. Стельмахович М. Народна дидактика. Київ, 1981.

3. Стельмахович М. Народне дитинознавство. Київ, 1985.

4. Стельмахович М. Педагогіка життя. Київ, 1980.

5. Стельмахович М. Українська родинна педагогіка. Київ, 1996.

6. Стельмахович М. Українське родинознавств. Івано-Франківськ, 1994.

7. Фіцула М. Педагогіка. Київ, 2000. 542 с.

\section{REFERENCES}

1. Savchenko, O.Ia. (2009). Vykhovnyi potentsial pochatkovoi shkoly [Educational potential of primary school]. Kyiv, 225 p. [in Ukrainian].

2. Stelmakhovych, M. (1981). Narodna dydaktyka [Folk didactics]. Kyiv. [in Ukrainian].

3. Stelmakhovych, M.(1985). Narodnedytynoznavstvo [Folk child studies]. Kyiv. [inUkrainian].

4. Stelmakhovych, M. (1980). Pedahohika zhyttia [Pedagogics of life]. Kyiv. [in Ukrainian].

5. Stelmakhovych, M. (1996). Ukrainska rodynna pedahohika [Ukrainian family pedagogics]. Kyiv. [in Ukrainian].

6. Stelmakhovych, M. (1994). Ukrainske rodynoznavstvo [Ukrainian genealogy family studies]. Ivano-Frankivsk. [in Ukrainian].

7. Fitsula, M. (2000). Pedahohika [Pedagogy]. Kyiv, 542 p. [in Ukrainian].

Стаття надійшла до редакції 19.08.2019

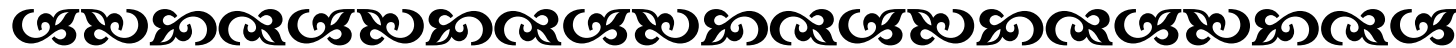

"Тізнай свій қрай...себе, Свій Ріd, свій народ, свою землю - $і$ ти побачии иляхх життя. ШАлх, на яқому найповніше розқриються твої здібності. ТТи даси йому продовження, вторувавши стежину, із тієї стежини вже рушили у життя твої нащадқи. I тақожбудеи ти".

Тригорій Сковорода уқраїнський білособ, педагог

“Сім'я - ие те первинне середовище, де людина повинна вчитися творити добро”. Василь Сухомлинський украйнський педагог

\section{G58080}

